\title{
Effects of Confining the Electron in a Double Quantum Well on the Excitonic Properties of the GaSb Quantum Ring
}

\author{
Mohamed Souhail Kehili1,2, Rihab Sellami ${ }^{1,2}$, Afef Ben Mansour ${ }^{1,2}$, Adnen Melliti1,2,* \\ ${ }^{1}$ Université de Carthage, Institut Préparatoire aux Etudes Scientifiques et Techniques, Laboratoire Matèriaux- \\ Molécules et Applications, BP51 La Marsa 2070, Tunisia \\ ${ }^{2}$ Université de Tunis, Ecole Nationale Supérieure des Ingénieurs de Tunis, 5 Rue Taha Hussein Montfleury, \\ 1008 Tunis, Tunisia
}

(Received 09 July 2020; revised manuscript received 15 December 2020; published online 25 December 2020)

\begin{abstract}
We studied theoretically the evolution of excitonic properties of GaSb quantum ring located inside the AlAs/GaAs/InGaAs/AlAs double quantum well with the wells (GaAs and InGaAs) thicknesses. The quantum ring is placed between the wells. In this type II nanostructure, the hole is confined inside the quantum ring and the electron is confined in the GaAs and InGaAs layers. The hole and the electron states were computed using the effective mass and the Hartree approximations. Then, the exciton energy, binding energy and lifetime were calculated. We found that varying the thickness of the well, we can control the localization of the electron wavefunction. Indeed, it can be above or below the quantum ring depending on the thicknesses of the GaAs and InGaAs layers. This has an important influence on the overlapping of the electron wavefunction with that of the hole which rests confined inside the quantum ring. Consequently, we can manipulate the excitonic properties, like energy, binding energy and lifetime via the electron and hole wavefunctions overlap. Thus, the studied systems can be used in tunable nano-optoelectronic devices. Furthermore, the use of the InGaAs layer as a capping layer of the quantum ring, instead of the GaAs layer as in an ordinary quantum ring, allows preserving the original properties of this nanostructure before the deposition of the capping layer.
\end{abstract}

Keywords: Exciton, Quantum ring, Effective mass approximation, Hartree approximation, Lifetime.

DOI: 10.21272/jnep.12(6).06002

PACS numbers: 7865K, 7320D

\section{INTRODUCTION}

Depending on the type of confinement, nanostructures can be classified into three groups: quantum dots (QDs) (0D), quantum wires (QWi) (1D) and quantum wells (QW) (2D). Each group has its unique properties. In particular, QDs have atom-like features resulting in a discrete density of states. Consequently, several works studied the fundamental properties [1-3] and the practical applications [4-13] of QDs. A special type of 0D nanostructures has been achieved since the late $90 \mathrm{~s}$ - the quantum ring $(\mathrm{QR})[1,14,15]$. This nanostructure showed improved performance in many applications as solar cells [4-7] and emission devices [11-13]. Specifically, GaSb/GaAs nanostructures gained more interest in the last decade, mainly due to their type II nature. Indeed, holes and electrons are spatially separated. The former are confined in the GaSb nanostructure and the later are free in the GaAs matrix. There are also other interesting features of these nanostructures that made them interesting, like the large valence band offset and the dynamics and interaction of charge carriers.

A key feature of nanostructures is the ability of tuning their physical properties, especially the excitonic and optical properties, by manipulating their structural and geometric properties. Particularly, the use of the dot-in-well structure (DWELL) increases the range of the achievable transition energy and opens new technological capabilities [16]. In one of our previous papers, the effect of confinement of the electron of the GaSb QR using an $\mathrm{Al}_{x} \mathrm{Ga}_{1-x} \mathrm{As} / \mathrm{GaAs}$ quantum well was studied [17]. We found that the electron confinement increases the exciton energy and optical transition probability. In the present paper, we investigate the manipulation of the excitonic and optical properties of the $\mathrm{QR}$ with different ways. For instance, we changed the electron confinement energy by varying the barrier height, the material of the barrier or the position of the $\mathrm{QR}$ inside the QW. These changes have strong effects on the transition energy, the exciton lifetime and the binding energy, which makes the GaSb QR more appropriate for several optoelectronic devices as lasers. To our knowledge, no research has been conducted on this subject.

The rest of this article is organized as follows. Section II is dedicated to present the results of the study of the effect of confining the electron on the excitonic properties of the GaSb QR embedded in the $\mathrm{AlAs} / \mathrm{GaAs} / \mathrm{InGaAs} / \mathrm{AlAs}$ double QW. Discussion of the use of this structure in different applications is given in section III. The conclusions are presented in section IV.

\section{RESULTS}

In this section, we study the effect of confining the electron on the excitonic properties of the GaSb QR embedded in the AlAs/GaAs/InGaAs/AlAs double QW (Fig. 1). InGaAs layer has a large lattice constant than GaAs that is used as a barrier in an ordinary $\mathrm{GaAs} / \mathrm{GaSb} \mathrm{QR}$. Thus, it imposes lower strain on the underlying ring. For QDs, the overlayer strain degrades the underlying dot [19] and the strain-reducing layer can preserve the original properties [20]. Hence the advantage of using such a layer also for QRs.

\footnotetext{
*adnenmelliti@yahoo.fr
} 


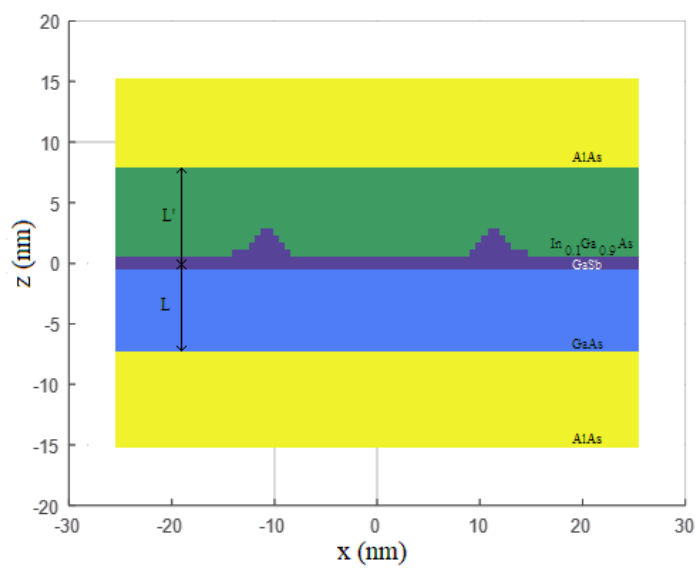

Fig. 1 - Cross-section of the $\mathrm{QR}$ in $\mathrm{Al}_{x} \mathrm{Ga}_{1-x} \mathrm{As} / \mathrm{GaAs} / \mathrm{InGaAs} /$ $\mathrm{Al}_{x} \mathrm{Ga}_{1-x} \mathrm{As}$ double QW: GaSb (dark blue), GaAs (light blue), In0.1Ga0.9As (green) and AlAs (yellow). The QR dimensions are: inner radius $9 \mathrm{~nm}$, outer radius $13 \mathrm{~nm}$ and height $2 \mathrm{~nm}$

The $\mathrm{QR}$ is placed above a wetting layer of a thickness of $0.56 \mathrm{~nm}$. The ring has the shape described by Fomin model [18] and an average diameter of $22 \mathrm{~nm}$ and a height of $2 \mathrm{~nm}$. These dimensions are similar to those typically found in the GaSb/GaAs QR [16].

The details of the computation are discussed in the previous work [17].

Fig. 2 shows the electron probability density for different values of the thicknesses of the upper $\left(L^{\prime}\right)$ and lower $(L)$ wells (Fig. 1). We see that the position of the $\mathrm{QR}$ in the QW has a substantial effect on the distribution of the electron wavefunction inside the well. This effect is attributed to different confinement energies of the two wells, which are related to the wells width and height. For $L^{\prime} \geq 5 \mathrm{~nm}$, the electron is mostly localized above the ring. For $L^{\prime}=2.5 \mathrm{~nm}$, the only values that give a wavefunction localized in the lower GaAs well are $L=7.5$ and $12.5 \mathrm{~nm}$. This effect has a considerable influence on the hole energy through the Coulomb interaction with the electron, as we will see later.

Fig. 3 shows the variation of the electron and hole energies with $L$ for different values of $L^{\prime}$. We see that the electron energy for $L^{\prime} \geq 5 \mathrm{~nm}$ is insensitive to the width of the lower well. For $L^{\prime}=2.5 \mathrm{~nm}$, the electron energy decreases with $L$. It is $300 \mathrm{meV}$ for $L=2.5 \mathrm{~nm}$ and then decreases to almost half of that value when $L=12.5 \mathrm{~nm}$, which is very close to the value of $L^{\prime}=5 \mathrm{~nm}$. As in the case of the electron, the hole energy has a small variation with $L$ for $L^{\prime} \geq 5 \mathrm{~nm}$. For $L^{\prime}=2.5 \mathrm{~nm}$ the curve has a minimum for $L=7.5 \mathrm{~nm}$, since in this position the electron wavefunction is closest to the ring, consequently the Coulomb interaction has its maximum value. The values for $L>7.5 \mathrm{~nm}$ are lower than those for $L<7.5 \mathrm{~nm}$. This difference originates from the different Coulomb interactions sensed by the hole in the two situations: the Coulomb interaction is slightly stronger when the electron is located above the ring $(L<7.5 \mathrm{~nm})$ than below it $(L>7.5)$.

Fig. 4a shows the variation of the exciton energy with $L$ for different values of $L^{\prime}$. We see the same dependence on $L^{\prime}$ and $L$ as in the electron energy case, since the variation of the hole energy is very small.
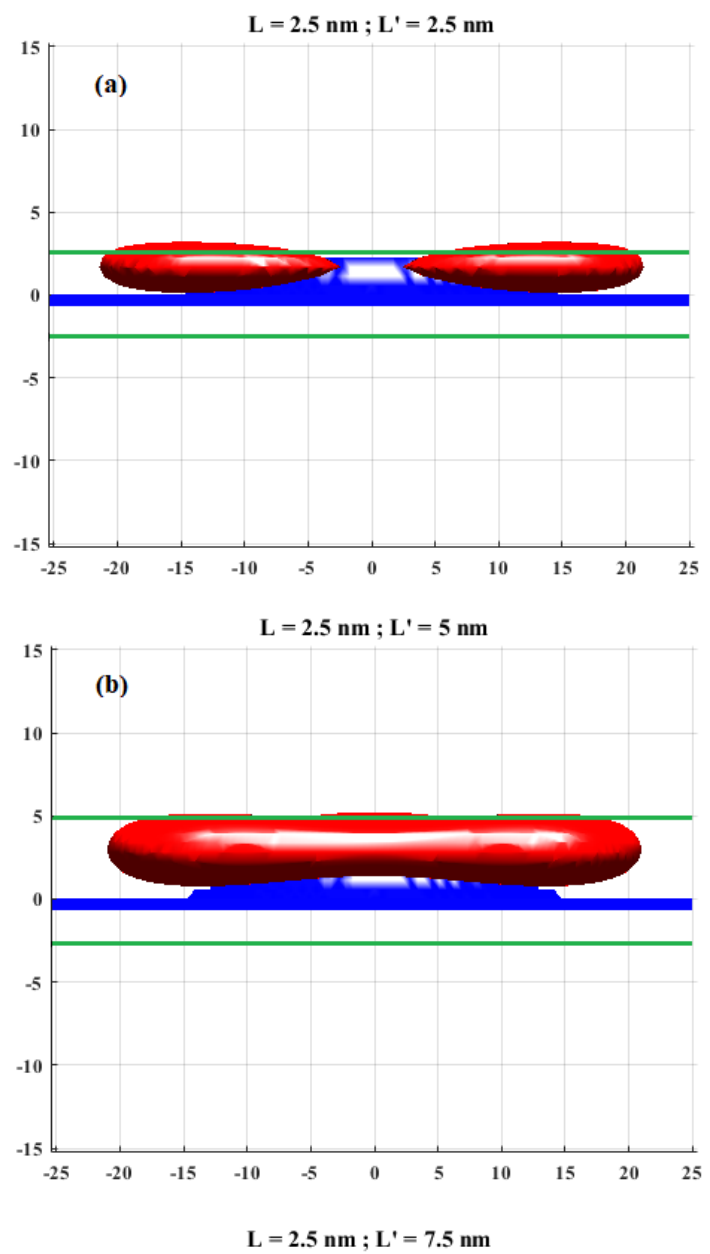

(c)
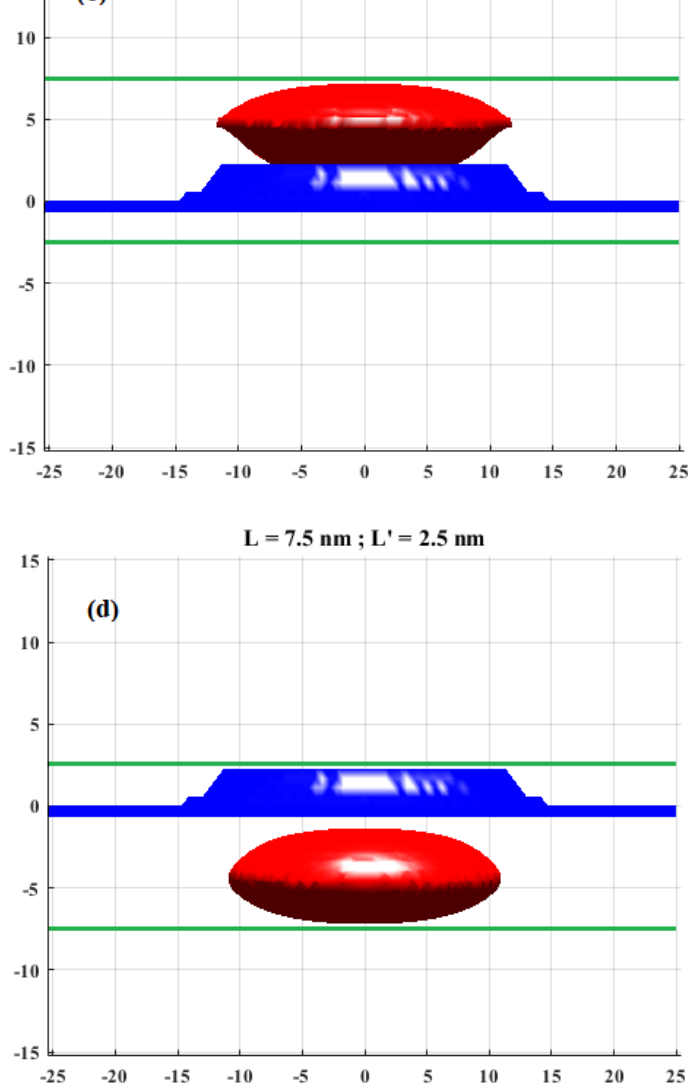

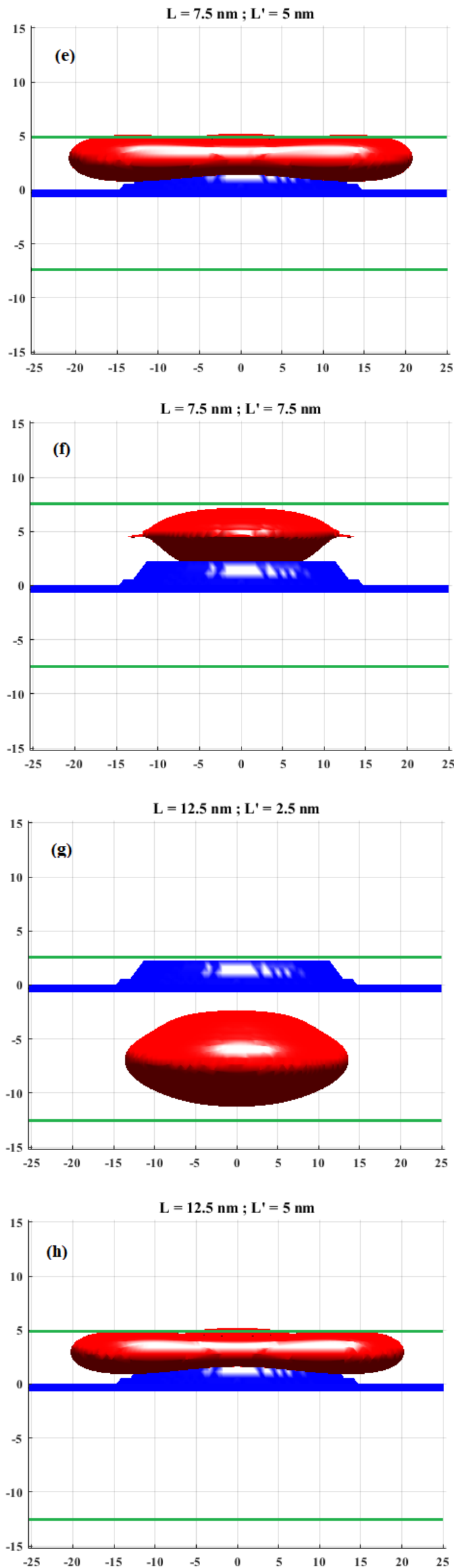

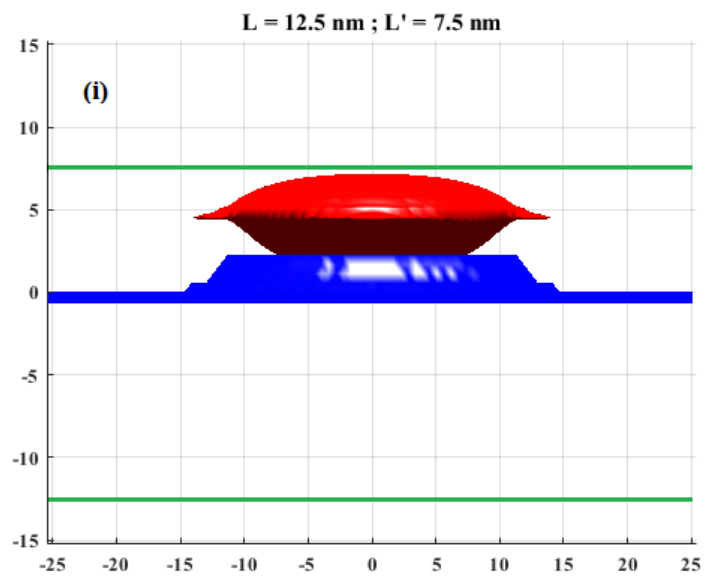

Fig. 2 - (a)-(i) Electronic probability density isosurface (70 \%) of the ground state for different values of $L$ and $L^{\prime}$, GaAs/AlAs and $\mathrm{AlAs} / \mathrm{In}_{0.1} \mathrm{Ga}{ }_{0.9} \mathrm{As}$ interfaces are indicated with green lines
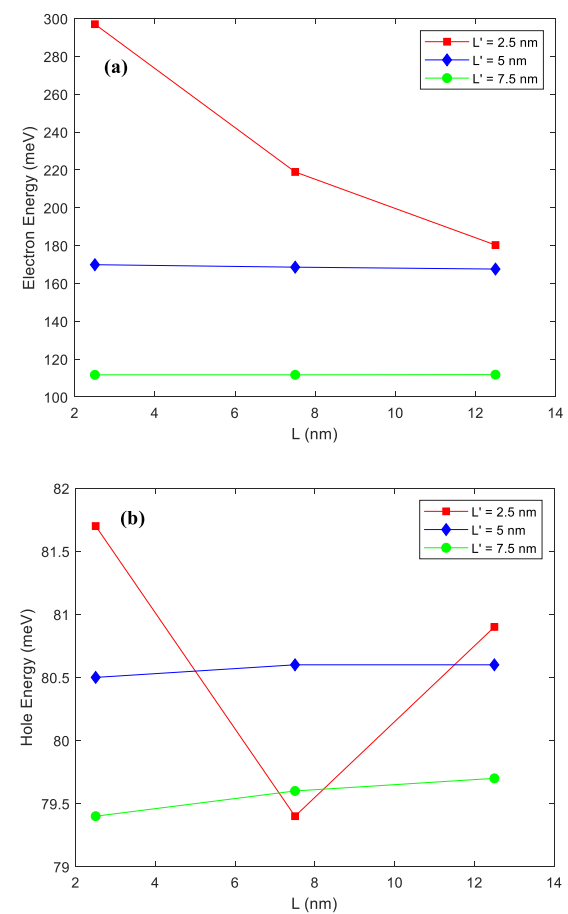

Fig. 3 - (a) Electron and (b) hole ground-state energies as a function of the position $L$ for different values of $L^{\prime}$

We conclude that $L$ and $L^{\prime}$ have an important effect on the exciton energy up to $180 \mathrm{meV}$. Fig. $4 \mathrm{~b}$ shows the exciton binding energy for different widths. We notice that the binding energy has a similar, but inverse, behavior to the hole energy. The minimum binding energy occurs for the smallest width used for both wells $(2.5 \mathrm{~nm})$, where the electron is located in the upper well around the QR. The highest value corresponds to $L^{\prime}=2.5 \mathrm{~nm}$ and $L=7.5 \mathrm{~nm}$, which is not so far from the value $L^{\prime}=7.5 \mathrm{~nm}$. In these two cases, the electron is located in the center of the structure and directly above the $\mathrm{QR}$ for $L^{\prime}=7.5 \mathrm{~nm}$ and below it for $L^{\prime}=2.5 \mathrm{~nm}$ and $L=7.5 \mathrm{~nm}$.

Fig. 5 shows the exciton lifetime for different widths. The structure with $L^{\prime}=5$ and $L=7.5 \mathrm{~nm}$ gives the lowest lifetimes, because the overlap is maximum, 
since the electron is very close to the QR. Additionally, these structures have practically the same lifetimes and are insensitive to the well width $L$. For the case of $L^{\prime}=2.5 \mathrm{~nm}$, a minimum value of $0.4 \mu \mathrm{s}$ is obtained for $L=7.5 \mathrm{~nm}$ and the lifetime reaches a maximum value of $2 \mu \mathrm{s}$ for $L=12.5 \mathrm{~nm}$ indicating that this structure gives the lowest overlap.
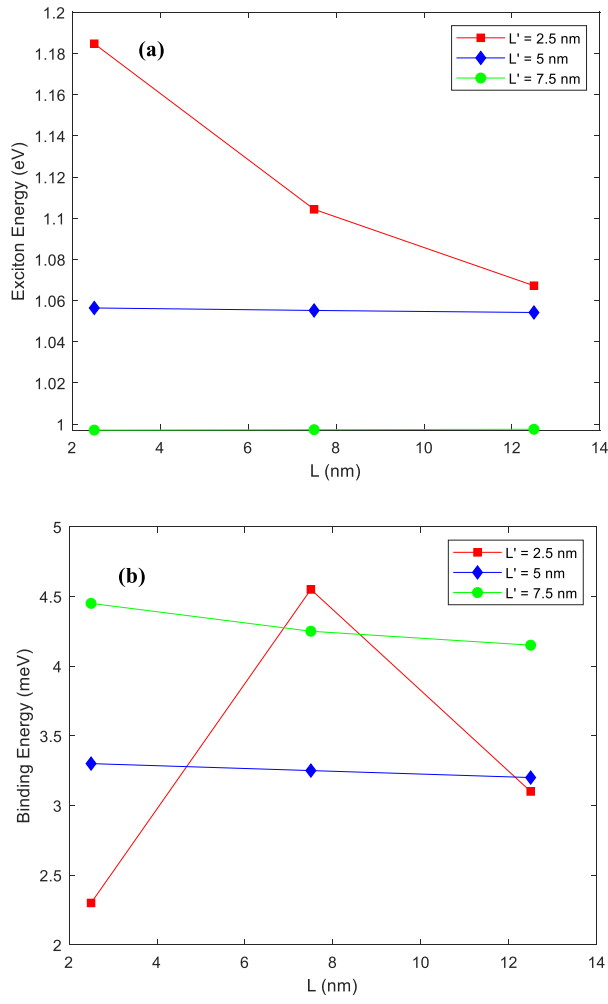

Fig. 4 - (a) Exciton and (b) binding energies of the exciton as a function of the position $L$

\section{DISCUSSION}

As mentioned in the introduction, 0D structures have advantages over existing semiconductor technologies for electronic and optical devices: solar cells, memory devices, lasers, sensors. The most important fundamental properties for the operation of these devices are the transition energy, the radiative lifetime

\section{REFERENCES}

1. A. Sahli, A. Melliti, M.A. Maaref, C. Testelin, A. Lemaitre, R. Kuszelewicz, P. Voisin, phys. status solidi b 244, 2622 (2007).

2. A. Melliti, M.A. Maaref, B. Sermage, J. Bloch, F. Saidi, F. Hassen, H. Maaref, Physica E 28, 22 (2005).

3. N. Sellami, A. Melliti, R. Othmen, M.A. Maaref, R. Kuszelewiez, A. Lemaître, J. Lumin. 131, 1641 (2011).

4. M.C. Wagener, D. Montesdeoca, Q. Lu, A.R.J. Marshall, A. Krier, J.R. Botha, P.J. Carrington, Sol. Energy Mater. Sol. C. 189, 233 (2019).

5. Y.I. Mazur, V. Lopes-Oliveira, L.D. d. Souza V. Lopez-Richard, M.D. Teodoro, V.G. Dorogan, M. Benamara, J. Wu, G.G. Tarasov, E. Marega Jr., Z.M. Wang, G.E. Marques, G.J. Salamo, J. Appl. Phys. 117, 154307 (2015).

6. H. Fujita, P.J. Carrington, M.C. Wagener, J.R. Botha, A.R.J. Marshall, J. James, A. Krier, K.-H. Lee, N.J. EkinsDaukes, Prog. Photovolt. 23, 1896 (2015). and the binding energy, which we have calculated in this paper for different structures. We studied here different ways to manipulate these properties to make the GaSb QR in the AlAs/GaAs/InGaAs/AlAs double QW system adequate for different applications. For lasers and photodetectors applications $[13,18]$, where a shorter lifetime is needed, the structure with $L^{\prime}=5$ and $L=7.5 \mathrm{~nm}$ ( $L^{\prime}$ and $L$ are the thicknesses of the upper and lower wells, respectively) is the best choice.

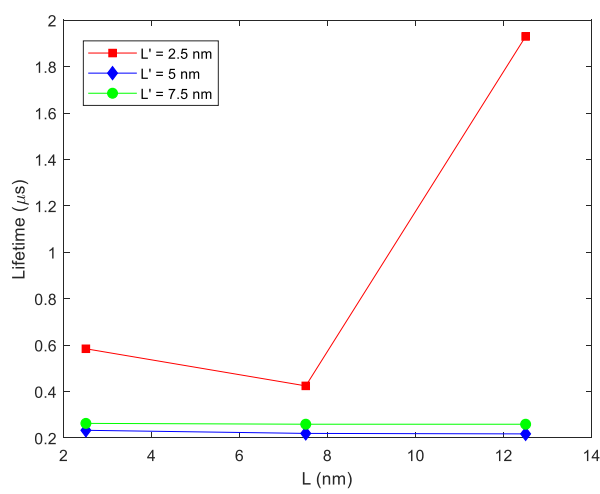

Fig. 5 - Radiative lifetime as a function of the position $L$ for different values of $L^{\prime}$

\section{CONCLUSIONS}

A theoretical study of the excitonic and optical properties of the type II GaSb QR located inside the $\mathrm{AlAs} / \mathrm{GaAs} / \mathrm{InGaAs} / \mathrm{AlAs}$ double QW was made in this article. The investigation is done by calculating the wavefunctions and energies of the electron and hole using the effective mass approximation. The Coulomb interaction is taken into account in the scope of the Hartree approximation. Then the exciton energy, the binding energy and the lifetime are calculated. We found that excitonic properties can be modulated considerably by changing the parameters of the studied structures via the manipulation of the localization of the electron wavefunction in the wells and consequently its overlap with that of the hole. Particularly, the lifetime can be varied between 0.2 and $2 \mu \mathrm{m}$. The exciton energy can be varied between 1 and $1.2 \mathrm{eV}$. Thus, these structures are promising candidates for application in tunable nano-optoelectronic devices.

7. D. Montesdeoca, P.J. Carrington, I.P. Marko, M.C. Wagener, S.J. Sweeney, A. Krier, Sol. Energy Mater. Sol. C. 187, 227 (2018).

8. A. Marent, M. Geller, A. Schliwa, D. Feise, K. Pötschke, D. Bimberg, N. Akçay, N. Öncan, Appl. Phys. Lett. 91, 242109 (2007).

9. T. Nowozin, L. Bonato, A. Högner, A. Wiengarten, D. Bimberg, W-H Lin, S.-Y. Lin, C.J. Reyner, L.L. Baolai, D.L. Huffaker, Appl. Phys. Lett. 102, 052115 (2013).

10. M. Hayne, R.J. Young, E.P. Smakman, T. Nowozin, P. Hodgson, J.K. Garleff, P. Rambabu, P.M. Koenraad, A. Marent, L. Bonato, A. Schliwa, D. Bimberg, J. Phys. D: Appl. Phys. 46, 264001 (2013).

11. J. Tatebayashi, A. Khoshakhlagh, S.H. Huang, G. Balakrishnan, L.R. Dawson, D.L. Huffaker, D.A. Bussian, H. Htoon, V. Klimov, Appl. Phys. Lett. 90, 261115 (2007).

12. W.-H. Lin, K.-W. Wang, S.-W. Chang, M.-H. Shih, S.-Y. Lin, 
App. Phys. Lett. 101, 031906 (2012).

13. W.-H. Lin, K.-W. Wang, S.-Y. Lin, M.-C. Wu, J. Crystal Growth 378, 571 (2013).

14. J.M. García, G. Medeiros-Ribeiro, K. Schmidt, T. Ngo, J.L. Feng, A. Lorke, J. Kotthaus, P.M. Petroff, Appl. Phys. Lett. 71, 2014 (1997).

15. W. Ouerghui, J. Martinez-Pastor, J. Gomis, A. Melliti, M.A. Maaref, D. Granados, J.M. Garcia, Eur. Phys. J.: Appl. Phys. 35, 159 (2006).

16. P.D. Hodgson, M. Hayne, A.J. Robson, Q.D. Zhuang, L. Danos, J. Appl. Phys. 119, 044305 (2016).
17. M.S. Kehili, A.B. Mansour, R. Sellami, A. Melliti, Semicond. Sci. Technol. 33, 115019 (2018).

18. V.M. Fomin, V.N. Gladilin, S.N. Klimin, J.T. Devreese, N.A.J.M. Kleemans, P.M. Koenraad, Phys. Rev. B 76, 235320 (2007).

19. R. Songmuang, S. Kiravittaya, O.G. Schmidt, J. Crystal Growth 249, 416 (2003).

20. K. Kuldová, V. Křápek, A. Hospodková, J. Oswald, J. Pangrác, K. Melichar, E. Hulicius, M. Potemski, J. Humlíček, phys. status solidi c 3,3811 (2006).

\title{
Вплив обмеження електрона в подвійній квантовій ямі на екситонні властивості квантового кільця GaSb
}

\author{
Mohamed Souhail Kehili1,2, Rihab Sellami1,2, Afef Ben Mansour ${ }^{1,2}$, Adnen Melliti1,2 \\ ${ }^{1}$ Université de Carthage, Institut Préparatoire aux Etudes Scientifiques et Techniques, Laboratoire Matèriaux- \\ Molécules et Applications, BP51 La Marsa 2070, Tunisia \\ ${ }^{2}$ Université de Tunis, Ecole Nationale Supérieure des Ingénieurs de Tunis, 5 Rue Taha Hussein Montfleury, \\ 1008 Tunis, Tunisia
}

\begin{abstract}
Ми теоретично вивчали еволюційні екситонні властивості квантового кільця GaSb, розташованого всередині подвійної квантової ями $\mathrm{AlAs} / \mathrm{GaAs} / \mathrm{InGaAs} / \mathrm{AlAs}$, залежно від товщин ям (GaAs та InGaAs). Квантове кільце розміщують між ямами. У цій наноструктурі II типу дірка утримуеться всередині квантового кільця, а електрон обмежуеться шарами GaAs та InGaAs. Діркові та електронні стани були обчислені з використанням ефективної маси та наближень Хартрі. Потім розраховували енергію екситону, енергію зв'язку та тривалість життя. Ми виявили, що змінюючи товщину ями можна контролювати локалізацію електронної хвильової фрункції. Дійсно, вона може бути вище або нижче квантового кільця в залежності від товщин шарів GaAs та InGaAs. Це мае важливий вплив на перекриття електронної хвильової функції із хвильовою функцією дірки, яка обмежена квантовим кільцем. Отже, ми можемо керувати екситонними властивостями, такими як енергія, енергія зв'язку та тривалість життя, шляхом перекриття електронних та діркових хвильових функцій. Таким чином, досліджувані системи можуть бути використані в регульованих нано-оптоелектронних пристроях. Крім того, використання шару InGaAs як шару покриття квантового кільця замість шару GaAs, як у звичайному квантовому кільці, дозволяе зберегти вихідні властивості ціеї наноструктури до осадження шару покриття.
\end{abstract}

Ключові слова: Екситон, Квантове кільце, Наближення ефективної маси, Наближення Хартрі, Тривалість життя. 